\title{
Public Policy Formulation Based on Local Wisdom in Kenteng Village, Semarang Regency
}

\author{
Suprayogi ${ }^{1}$, Erisandi Arditama ${ }^{2}$, Eta Yuni Lestari ${ }^{3}$, Novia Wahyu Wardhani ${ }^{4}$, Yudha \\ Pratama Widiyanto ${ }^{5}$, Syahrul Hafidz Gunawan ${ }^{6}$ \\ ${ }^{1-6}$ Department of Politics and Citizenship, Faculty of Social Sciences, Unnes \\ *Corresponding author. Email: suprayogi@mail.unnes.ac.id
}

\begin{abstract}
The study of public policy from the process side is a study that emphasizes the process dimension in its formulation. As a process, public policy has stages start from the formulation until the implementation. This paper is interesting because it seeks to explain the process of formulating public policies based on local wisdom in Kenteng Village, Semarang Regency. By using a case study and a qualitative research approach, this paper finds some interesting things. First, as a process, the formulation of public policies in Kenteng Village is carried out on a bottom-up basis, namely accommodating the voices and aspirations of the hamlet residents. Second, efforts to accommodate the aspirations of the hamlet residents are carried out in a friendly manner based on village local wisdom. Third, tilikan dusun is a place to convey the aspirations of hamlet residents as well as a space for village government communication with hamlet residents. Fourth, tilikan dusun is also a point of collaboration between the village government and hamlet residents based on local wisdom in Kenteng Village, Semarang Regency.
\end{abstract}

Keywords: Public Policy Formulation, Local Wisdom, tilikan dusun.

\section{INTRODUCTION}

Public policy, both at the study level and at the practical level, is closely related to aspirations. Because aspirations are an important part of public policy from a process perspective or a systems approach. However, absorbing public aspirations in the process of formulating public policies is not a simple and easy matter. The main reason is, in the process of absorbing aspirations, there are various actors who have different interests.

The issue of absorbing the aspirations of citizens at each level of government is often quite complex. This is because efforts to absorb citizens' aspirations involve many actors with a variety of interests. Likewise with the dynamics of absorbing aspirations at the village level. Even though the villagers have a homogeneous character, absorbing the village's aspirations also has its dynamics. Conflicts of interest often also occur because there are misunderstandings among villagers regarding their perspective in responding to public problems and village government policies.

Kenteng Village in Semarang Regency has an interesting strategy to absorb the aspirations of the residents. This strategy is called tilikan dusun. This activity is a moment when the village government comes to hear the aspirations of the residents in each hamlet. This is done to absorb the aspirations of hamlet residents, explain existing public policies, and build good communication with hamlet residents. The hope is that harmony will be realized in Kenteng Village itself.

In addition, the hamlet government also has space to explain the existing problems and the policies taken to overcome them. It is at this point that the space for policy synchronization between the village government and the hamlet government is realized. Both misunderstandings in the context of the socialization of village government policies, the perspective on seeing a public problem, and the issues raised in the absorption of the aspirations of the 
villagers. So that the tilih dusun is expected to minimize misunderstandings regarding a public policy taken by the Kenteng Village government

\section{LITERATURE REVIEW}

Conceptually, public policy has a process dimension both theoretically and practically. This process dimension emphasizes efforts to understand and explain how public policies are formulated and socialized. As we know, public policy is a continuity system between one phase and another phases. From this basic logic, it can be concluded that public policy is an activity process that has a phase or stages of activity. The model of public policy as an activity process was introduced by David Easton which emphasized the existence of an input element (demand and support), a political system, then become an output (decision or policy). At this point the process dimension in public policy begins (Mas'oed and Andrew, 2006). Later, seeing public policy as a process will be developed by several experts, including Parson who sees public policy as a policy process and cycle (Parson, 2005 in Muadi, MH, and Sofwani, 2016)

In subsequent developments, Thomas R. Dye developed Easton's ideas by developing more specifically and sharpening several phases, which include: identification or policy problems, agenda setting, policy formulation, policy legitimation, policy implementation, and policy evaluation (Dye, 1995). From the development of a public policy model as a Dye-style process, it is able to provide a complete foundation related to a systemic and directed policy formulation process. The hope is that the converted input in a political system will be able to produce policy outputs (Easton model) that are quality, right on target, and effective.

The strengths of this model can provide a complete foundation for a systemic and directed policy formulation process. Its main weakness lies in the dominant technocratic approach. However, this model still leaves room for critical dialectics. The critical power and foresight of each actor related to the policy formulation process are absolute. If not, the use of this model will be ignored on the political side through conflicts of interest and insensitive to the contextual dimensions that always accompany every policy reality (Santoso, 2010).

Efforts to produce accommodative and aspirational output when formulating public policies require the good capacity to absorb aspirations. The absorption of these aspirations has a function to identify problems in the public policy formulation process. Because identifying public problems is a very fundamental part of the public policy process (Bintari and Pandiangan, 2016). Both procedural public problems and substantive public problems (Winarno, 2008 and Nugraha, 2017). Besides to providing input to policymakers, it is also to build togetherness with affected actors if public policies have been or are to be drawn up. Likewise in the context of Kenteng Village in Semarang Regency. absorbing aspirations based on communication with hamlet residents is an effort to accommodate the aspirations of the hamlet residents as well as an effort to build togetherness between the residents and the Kenteng Village government.

\section{DISCUSSION}

Kenteng Village is one of the villages located in Bandungan, Semarang regency. This village consists of 7 hamlets, namely Gelaran, Clowok, Jurang, Galah, Kenteng, Ampel Gading, Karanglo. Kenteng Village has one BUMDes (village-owned enterprised) and several tourist attractions. Both BUMDes (village-owned enterprised) and tourism are managed by the village. Decision making, including decisions about village tourism policies only involves the internal village of Kenteng. That is, it remains the village government that decides. Meanwhile, the aspirations as policy input came from the residents of Kenteng Village.

The Kenteng Village Government has an interesting strategy in capturing the aspirations of each hamlet. The village government through the tilikan dusun program will tour from one hamlet to another to hold meetings and discuss the program plans of each hamlet. In the meeting, the village government hopes that the hamlet community already has a priority scale for realization, making it easier for the village government to map out programs to be realized.

Policy-making in Kenteng Village was initiated through the Hamlet Deliberation (Musdus) which was held to gather community aspirations through meeting forums of each RT with its residents. This forum is a forum for dialogue and discussion, as well as a space to absorb the aspirations of RT residents. After going through the Musdus, the aspirations were brought to the village deliberation forum by the hamlet head. Furthermore, the village apparatus will sort the aspirations based on priority or needed or urgent. The village apparatus will directly review the aspirations that have been sorted according to these priorities for follow-up. The follow-up process is based on the village budget. If the budget is deemed insufficient in the realization process, the implementation will be postponed next year.

As the government as well as the facilitator, the village government has issued several village policy 
products in the form of village regulations, decrees (SK), and village head regulations. The regulation as a guideline through village meetings with the BPD (playing a role in capturing the aspirations of the community) will later result in village regulations and village head regilations that elaborate village regulations which are more technical. According to Mrs Ana as the Secretary of Kenteng Village, the SK channel is issued by the village head according to the existing needs to protect the status or role to assist the village head's duties.

At this point, the role of the village government is apart from being the administrator of the government as well as a facilitator to organize several forums for village meetings. This is done to absorb aspirations as input from citizens before formulating policies. The meeting forums that held are village meetings and the tilikan dusun. The village government accompanies the BPD in accepting the aspirations of the community for further discussion at the sub-district to regency levels. This method is done so that these aspirations can be realized. Thus, the role of the village government as facilitator is truly effective by guarding aspirations until become public policies that are ready to be implemented.

In addition, there are interesting things when capturing aspirations as previously written. The way of the village government captures aspirations to formulate public policies is carried out through local wisdom which is called the tilikan dusun. The tilikan dusun practice in Kenteng Village is carried out once a year and is carried out in turns from the hamlet for a certain period of time, either one month or one week according to the schedule agreed upon by the village apparatus and the hamlet head.

As stated by Mrs Ana as the village secretary, tilikan dusun is a routine activity carried out by the village government to see the areas in Kenteng Village. The Tilikan dusun is usually held once or twice a year. This was attended by village officials, hamlet heads, religious leaders, and community and community leaders in the hamlet.

Through this forum, the village government conveyed information about village programs that will be implemented over the next year. The community can respond and convey aspirations related to the programs delivered by the village government. In this activity, there is also an exploration of the idea of meeting directly with the community to get input or listen to complaints they experience or need.

\section{PRACTICE DYNAMICS OF TILIKAN DUSUN}

According to Mr. Pramono, the Head of Jurang hemlet, tilikan dusun is a village program and is carried out once a year. What is conveyed in the tilikan dusun process includes the delivery of development programs or matters of administrative stewardship such as family cards, correspondence, and so on. Usually, the hamlet head gathers around 70 people to follow the hamlet's scrutiny. During a pandemic like now, the tilikan dusun program has not been implemented.

According to him, the tilikan dusun program has had a real impact, for example, such as road construction using concrete, although some aspirations have not been realized that will be implemented next year. This is done based on the priority scale made or there is an urgent situation. He also explained that the current focus is on the economic development of the community after the impact of this pandemic, such as the cultivation of Chrysanthemum Flowers which is the economic driver of about $70 \%$ of the residents in this Jurang hemlet.

Tilikan dusun in Jurang hemlet is usually carried out at Mr. Pramono's house. He has been the head of the hamlet for 20 years and he once proposed coaching the villagers in addition to the hamlet surveillance program. According to him, this village community development has targets to be achieved so that it is hoped that they can build a community to be independent, it's just that his proposal has not yet been implemented. In his hamlet surveillance activities, he focuses on overseeing irrigation and farming policies as an agricultural center. Before the hamlet surveillance was carried out, the hamlet residents usually gave their aspirations through meetings such as the Yasinan going around every Friday night which was carried out within the scope of the RT.

According to Mr. Mudrianto, Head of Karanglo Hamlet, tilikan dusun begins with the process of conveying information to the residents regarding village programs, but also by absorbing the aspirations that exist in the community. One of the aspirations that have been fulfilled is the construction of a concrete road as the main access to the hamlet and also the construction of a road in Karang Wetan. Tilikan dusun is carried out once a year but during a pandemic like now this program has not been implemented.

Other information obtained from him was that several aspirations such as training and so on were often suggested by the PKK. According to him, if it is to be implemented, the tilikan dusun should be more focused on improving the economy. He also said that the development that is being carried out also does not have to be proposed through tilikan dusun, although in the future only 2 can be raised in the realm of village deliberations. Meanwhile, other plans were postponed 
and prioritized which became the priority needs of the community.

Other information was conveyed by $\mathrm{Mr}$. Bambang, Head of Clowok Hamlet. He said that the tilikan dusun was a forum to convey village programs by the village government. To convey the aspirations of the residents and program planning, this is conveyed through the hamlet deliberation forum (Musdus). He also said that monitoring the tilikan dusun is a formality, but there is also real evidence in the form of the construction of connecting roads between hamlets. The development was carried out well. Then for programs that have not been realized this year, they will be implemented next year.

The information from Mr. Mudrianto and Mr. Bambang are interesting. According to both, tilikan dusun is not the only space to convey aspirations for the residents of Kenteng Village. However, the tilikan dusun momentum remains a distinctive momentum. This is because, in addition to being a tradition for the village government to listen to the aspirations of its citizens, it is also a space for conveying popular aspirations, interactions, and communications. With its popularity, the hamlet's scrutiny has become an interesting and unique momentum. Therefore, the aspirations that are conveyed will feel different if the aspirations are conveyed in other meeting forums.

Meanwhile, according to Mr. Amin, Head of Golak hemlet, the tilikan dusun process is indeed only carried out once a year. However, this year there is no plan to hold another tilikan dusun, considering that the pandemic period has yet to end. He expressed his views regarding the process of implementing tilikan dusun, which should not only be the delivery of programs from the village. This was considered ineffective because the village head could directly convey information about the village program and then forward it to the community. In addition, according to him, the aspirations that were brought through the hamlet surveillance forums and hamlet deliberations were not fully realized so that it seemed an only formality.

The information conveyed by the informants explained to us how tilikan dusun is a space for interaction, communication, socialization, and a space to capture the aspirations of villagers. The tilikan dusun has an important position because it has a complexity of goals even though the main thing is as a space to collect aspirations. In addition, the coverage of tilikan dusun aspirations is also wider than the hamlet deliberations. So that the tilikan dusun is still held until now because it is considered a meeting forum that is quite important and strategic.

\section{CONCLUSION}

Public policy is an activity process that has a phase or stages of activity. Public policy formulation studies often touch on formal and technocratic dimensions. However, in Kenteng Village, the formulation of public policies was carried out through an informal approach based on local wisdom. The Kenteng Village Government has an interesting strategy in capturing the aspirations of each hamlet. The village government through the tilikan dusun program will tour from one hamlet to another to hold meetings and discuss the program plans of each hamlet. Tilikan dusun is a village program and is carried out once a year that includes the delivery of development programs or matters of administrative stewardship such as family cards, correspondence, and so on. Tilikan dusun is an important space to discuss public issues both procedurally and substantively. Tilikan dusun is also a space to obtain input in the form of aspirations of hamlet residents as well as village residents as a basis for formulating public policies later. Whether it is a space for interaction between the village government and residents or as a space for kinship between villagers and the village government. Tilikan dusun has become a bridge between actors related to the formulation of public policies in Kenteng Village. Tilikan dusun program has had a real impact, for example, such as road construction using concrete. Although in practice, tilikan dusun is not yet fully an aspirational space, but the existence of a space for aspirations based on local wisdom has been an advancement for the study of the politics of public policy itself.

\section{REFERENCES}

[1] Bintari, A., \& Pandiangan, L. S. (2016). Formulasi Kebijakan Pemerintah tentang Pembentukan Badan Usaha Milik Daerah (BUMD) Perseroan Terbatas (PT) Mass Rapid Transit (MRT) Jakarta di Provinsi DKI Jakarta. Jurnal Ilmu Pemerintahan.

[2] Dye, T. R. (1995). Understanding Public Policy. New Jersey: Prentice Hall.

[3] Mas'oed, M., \& Andrews, C. M. (2006). Perbandingan Sistem Politik. Yogyakarta: Gadjah Mada University Press.

[4] Muadi, S., MH, I., \& Sofwani, A. (2016). Konsep dan Kajian Perumusan Kebijakan Publik. Jurnal Review Politik.

[5] Nugraha, I. A. (2017). Proses Formulasi Kebijakan Penanggulangan Kemiskinan (Studi Kasus Unit Pelaksana Teknis Penanggulangan Kemiskinan Kabupaten Sragen). Jurnal Ilmu Politik.

[6] Parsons, W. (1997). Public Policy: An Introduction to The Theory and Practice of Policy Analysis. UK: Edward Elgar.

[7] Santoso, P. (2010). Modul Pembelajaran Analisis Kebijakan Publik. Yogyakarta: Polgov JPP UGM.

[8] Winarno, B. (2008). Kebijakan Publik: Teori dan Proses. Yogyakarta: MedPress. 